\title{
A INTOLERÂNCIA RELIGIOSA E AS VIOLAÇÕES DE DIREITOS CONTRA OS PRATICANTES DA UMBANDA
}

\section{LETÍCIA CHEAB DE FREITAS FRANÇA}

Graduanda em Direito, modalidade integral, pela Escola Superior Dom Helder Câmara. Belo Horizonte - MG. E-mail: leticiacheab@yahoo.com.br.

\section{LUÃ TOLEDO CASTRO}

Graduando em Direito, modalidade integral, pela Escola Superior Dom Helder Câmara. Belo Horizonte - MG. E-mail: luatoledo@hotmail.com.

CAIO AUGUSTO SOUZA LARA Mestre e Doutor em Direito pela Faculdade de Direito da Universidade Federal de Minas Gerais - UFMG. Professor da Escola Superior Dom Helder Câmara. Pesquisador Associado ao Programa RECAJ-UFMG - Acesso à Justiça e Solução de Conflitos. Secretário de Comunicação do Conselho Nacional de Pesquisa e Pósgraduação em Direito - CONPEDI. Belo Horizonte-MG. E-mail: caiolarabh@yahoo.com.br.

\section{RESUMO}

O tema-problema da pesquisa que se pretende desenvolver é a intolerância religiosa e as violações de direitos contra os praticantes da religião Umbanda, fato social originado da desinformação e pelo preconceito com as religiões de matriz africana. Após a análise de muitos depoimentos de adeptos da religião, foi possível observar que existe um certo temor em se assumir como umbandista. Isto ocorre porque ela é malvista por aqueles que não buscam conhecimento histórico, cultural e religioso da umbanda. Além disso, o terreiro, ainda hoje, é visto por muitos como local 
Personalidade Acadêmica Homenageada:

Raymundo Juliano Feitosa (Universidade Federal do Rio Grande do Norte - UFRN)

de feitiçaria, aonde vão para fazer pedidos maléficos, amarrações e oferendas demoníacas. Alguns se assumem até mesmo como católicos para não sofrerem represálias. Segundo o jornal Carta Capital, até o final de setembro do ano de 2017, ocorreu o maior número de registros já apresentados de intolerância religiosa no país, foram contabilizados pelo menos 79 ataques contra terreiros ou adeptos de religiões de matriz africana. Esses ataques demonstram a falta de liberdade religiosa e todo 0 preconceito presente por causa de racismo, mentiras e falta de informação sobre o que é a Umbanda. Ainda são diversas e poderosas as formas de colonização e exclusão do povo negro e sua religiosidade. Combater a intolerância religiosa significa rejeitar o racismo como sistema de opressão e dar voz a uma parcela da população que vem sendo sistematicamente agredida em sua dignidade pela censura de direito à liberdade de culto. O problema objeto da investigação científica proposta é: no Brasil contemporâneo, quais os problemas jurídicos e sociológicos vivenciados pelos umbandistas em função de sua religião? A partir das reflexões preliminares sobre 0 tema, é possível afirmar inicialmente que os praticantes da religião Umbanda não tem seus rituais respeitados pelos protestantes, principalmente pela ação de movimentos neopentecostais e conservadores da sociedade, que nos últimos anos teriam se valido de mitos e preconceitos para "demonizar" e insuflar a perseguição a umbandistas e candomblecistas, principalmente pelo racismo enraizado na sociedade que gera essa intolerância com religiões afro-brasileiras. O objetivo geral do trabalho é analisar a condição dos praticantes da Umbanda e o impedimento da livre prática da religião no contexto da intolerância religiosa no Brasil contemporâneo. A pesquisa que se propõe pertence à vertente metodológica jurídico-sociológica. No tocante ao tipo de investigação, foi escolhido, na classificação de Witker (1985) e Gustin (2010), o tipo jurídico-projetivo. O raciocínio desenvolvido na pesquisa será predominantemente dialético. De acordo com a técnica de análise de conteúdo, afirma-se que se trata de uma pesquisa teórica, o que será possível a partir da análise de conteúdo dos textos doutrinários, normas e demais dados colhidos na pesquisa. Como conclusão do trabalho, tem-se que é flagrante a violação dos direitos fundamentais dos praticantes da Umbanda e que o Brasil ainda tem um longo caminho de evolução na preservação das liberdades dos praticantes de religiões de matriz africana. As disposições 
Personalidade Acadêmica Homenageada:

Raymundo Juliano Feitosa (Universidade Federal do Rio Grande do Norte - UFRN)

constitucionais sobre a liberdade religiosa são violadas incessantemente na guerra religiosa presente em várias localidades. Numa próxima fase da pesquisa, serão realizados estudos jurisprudenciais para o estabelecimento de uma cartografia acerca da posição dos tribunais brasileiros sobre este tipo de violência.

PALAVRAS-CHAVE: Liberdade religiosa; Intolerância religiosa; Direitos Humanos.

\section{REFERÊNCIAS}

ANDRADE, Luiz Gustavo de; QUINTÃO, Bruna de Oliveira. Liberdade de religião e de escolha para fazer a doença e o dever de preservação da vida. Revista Jurídica UNICURITIBA. Vol. 27. № 11. 2011.Disponível em: http://revista.unicuritiba.edu.br/index.php/revjur/article/view/212/185. Acesso em: 20 maio 2019.

BRASIL TEM uma denúncia de intolerância religiosa a cada 15 horas. Portal Veja 13 nov. 2017. Disponível em: https://veja.abril.com.br/brasil/brasil-tem-uma-denunciade-intolerancia-religiosa-a-cada-15-horas/. Acesso em: 01 maio 2019.

CARVALHO, José Jorge de. As artes sagradas afro-brasileiras e a preservação da natureza. In: PALESTRA NO CENTRO DE CULTURA POPULAR, 2004, Brasília. Disponível em: http://midiaetnia.com.br/wp-content/uploads/2010/09/Serie381empdfArtesSagradas-Afro-brasileiras.pdf. Acesso em: 7 de maio de 2019.

GUSTIN, Miracy Barbosa de Sousa; DIAS, Maria Tereza Fonseca. (Re)pensando a pesquisa jurídica: teoria e prática. 3ª . ed. Belo Horizonte: Del Rey, 2010.

MOLINA, Danilo. A intolerância religiosa não vai calar os nossos tambores. Portal Carta Capital- 09 out. 2017 - Disponível em: https://www.cartacapital.com.br/diversidade/a-intolerancia-religiosa-nao-vai-calarosnossos-tambores/. Acesso em: 03 maio 2019.

PRANDI, Reginaldo. Entrevista com Reginaldo Prandi. Revista Último Andar. Junho de 2007. Disponível em: revistas. pucsp.br. Acesso em: 7 de maio 2019.

PRANDI, Reginaldo. Contos e lendas afro-brasileiros: a criação do mundo. São Paulo: Companhia das letras, 2007.

SANTOS, Ivair et al (organizadores). Intolerância religiosa no Brasil: relatório e balanço. Rio de Janeiro: Klínē, 2016. 
Personalidade Acadêmica Homenageada:

Raymundo Juliano Feitosa (Universidade Federal do Rio Grande do Norte - UFRN)

SIMÕES, Lucas. Policial lidera destruição de terreiro. Portal O Beltrano - Disponível em: $\quad$ https://www.obeltrano.com.br/portfolio/policial-lidera-destruicao-de-terreiro/. Acesso em: 01 maio 2019.

WITKER, Jorge. Como elaborar una tesis en derecho: pautas metodológicas y técnicas para el estudiante o investigador del derecho. Madrid: Civitas, 1985. 